\title{
THE MANAGEMENT OF MAINTENANCE TECHNOLOGY TRANSFER IN THE SOUTH AFRICAN AVIATION INDUSTRY
}

\author{
L.I. le Grange and A.J. Buys \\ Institute for Technological Innovation \\ University of Pretoria \\ ianl@hiveld.co.za, ajbuys@up.ac.za
}

\begin{abstract}
This paper reports on research into the technology transfer activities of South African aviation industry companies. The technologies surrounding the maintenance function were investigated, since this is one of the main functions in this industry. The investigation shows the extent to which technology is transferred from external sources to the individual companies. The investigation was also extended to cover internal technology transfer. The result of the investigation indicated the sources of technology, the mechanisms used for transfer, and the barriers to the transfer process both for internal and external technology transfer. The paper concludes with a look into what the future may hold for maintenance in the aviation industry given the current trend in technology development.
\end{abstract}

\section{OPSOMMING}

Hierdie artikel beskryf navorsing oor die tegnologie-oordrag aktiwiteite van Suid-Afrikaanse lugvaartnywerheidmaatskappye. Die tegnologieë wat verband hou met die onderhoudfunksie is ondersoek, aangesien dit een van die hooffunksies in dié nywerheidsektor is. Die ondersoek toon die omvang van tegnologie-oordrag van eksterne bronne na individuele maatskappye. Die ondersoek is uitgebrei om ook interne tegnologie-oordrag in te sluit. Die resultaat van die ondersoek het die bronne van tegnologie, die oordrag-meganismes en die versperrings tot interne en eksterne oordrag, geïdentifiseer. Die artikel sluit af met ' $n$ toekomsblik vir instandhouding vir die lugvaartnywerheid in die lig van huidige neigings in tegnologiese ontwikkeling. 


\section{BACKGROUND TO THE SA AVIATION INDUSTRY}

Since 1994 major changes have taken place in South Africa. These changes have affected many industries and the South African aviation industry is no exception. In a very short period of time new markets have opened that were previously inaccessible and a number of foreign operators have extended their services to South Africa.

In the past the aviation industry was forced to be self-sufficient and to operate without any assistance. This effected most areas inside the aviation industry, including the maintenance function. Parts needed to service aircraft were not always available and skills were therefore developed to repair most of the parts used on the aircraft. Very unique skills were developed during this time in order to ensure the availability of aircraft. Due to the unique circumstances, company cultures were established, which could be described by an attitude of 'we can do anything' and this was necessary in order to survive and continue operations.

Concepts like 'competition' and 'competitive advantage' did not receive the same attention as in companies operating in an open market. Many international carriers were not allowed to operate routes to South Africa and this limited the competition that South African carriers faced. It is clear that the industry functioned in an artificial market, where the market forces were different from what is traditionally expected. Companies in the industry became large organisations incorporating every aspect of the aviation industry 'under one roof'. The reason being that it was expected of these companies to be self-sufficient and diversified enough to handle anything. Traditional sources of technology were not that accessible and the industry relied heavily on skills and customised knowledge to keep the operation going.

This all changed after 1994 when South Africa was accepted back into the world community. One of the first industries to be exposed to the new dispensation was the aviation industry, as a result of the nature of its service, namely the transportation of passengers and cargo, internationally. Suddenly the industry experienced competition because large international carriers were allowed to service South African routes. The South African industry was forced to re-evaluate their position and had to be competitive in a global market. Even individual functions like 'maintenance' had to re-evaluate their position and objectives, as they too were faced with direct competition. Time and cost began to play a more important role, as these are competing factors in international market. The industry also started to follow international trends in a bid to become more competitive. Airlines started to focus on their core business of transporting passengers and goods, while outsourcing other functions like maintenance. Other sources of technology also started to open up and become more accessible.

\section{RESEARCH}

In a previous paper by the authors[1], a detailed review of the theory of technology transfer mechanisms was presented. In order to compare the South African Aviation industry to the theory concerning technology transfer, research was undertaken in the industry. The aim of the research was to investigate the technology transfer activities, with reference to the transfer mechanisms used in the South African aviation industry. The feeling is that not enough emphasis is placed on technology and the role technology can play in creating a competitive advantage in the market. The research aim was therefore to focus the attention of role-players 
in the South African aviation industry on technology. In order to obtain the most appropriate technology it must be transferred and the focus of the research was on the transfer of technology from an originator to a user of the technology. The research further focussed on technologies used in the aviation maintenance function.

The results of the research was used to test the following hypotheses, based on our current knowledge of the industry and the theory of technology transfer:

- Do South African companies transfer technology?

Hypothesis 1: Yes, technology is being developed outside the companies and therefore appropriate technologies are being transferred to the companies.

- How effective is the transfer process?

Hypothesis 2: Not very effective, due to the years of isolation.

- Is there a gap between the current technology used and the technology available? Hypothesis 3: Yes, due to the years of isolation and the lack of knowledge concerning the technology available to the companies.

- Are dedicated people and programmes looking into technology and the managing thereof?

Hypothesis 4: No, technology is not seen as an important enough aspect to have dedicated people managing it. This may be due to the fact that the industry is not dependent on in-house technology development. It may also be because the industry is technology followers, or technology is not seen as a factor for competitiveness.

- Do barriers influence the effective transfer of technology?

Hypothesis 5: Yes, there are many barriers to the transfer process like cost, red tape, ignorance, etc.

- Are current technologies fully exploited by the organisations?

Hypothesis 6: No, due to insufficient training, scepticism around the technology being used, etc.

\subsection{Research Methodology}

The research was done by means of a questionnaire consisting of 24 questions. Role players in the South African Aviation industry were contacted and asked to participate in the research project. The questionnaire was completed during a short interview with the relevant persons. The questionnaire was designed so that people throughout the hierarchy could participate in the research. The questionnaires were completed anonymously. The questionnaire consisted of five sections.

The methodology followed in the questionnaire was to first determine if transfer of technology takes place that is relevant to the participant. If the answer is 'yes', the sources of the technology were identified and also the effectiveness according to the participants perception. Following this the mechanisms of transfer are identified and also the effectiveness 
of the mechanisms, again according to the perception of the participant. The questionnaire then aimed to identify possible barriers to the transfer of technology and finally it determined the appropriateness of the technology transferred.

\subsection{Results and discussion}

In this section the results of the research are discussed. This includes both the results from the questionnaires as well as the results of the interviews. Firstly the results of the questionnaire interviews are discussed under the headings: internal technology transfer and external technology transfer. Thereafter a short discussion on the interviews follows.

\subsubsection{External Technology Transfer}

All the respondents replied 'yes' to the question whether their companies utilise opportunities to transfer technology from outside sources. These projects were perceived to be effective. Under the main sources utilised, OEM's were quoted 8 times, tertiary institutions once, contracting firms once and business modelling experts once. The average weights (out of ten) depicting the importance of the sources to the company can be seen in Figure 1.

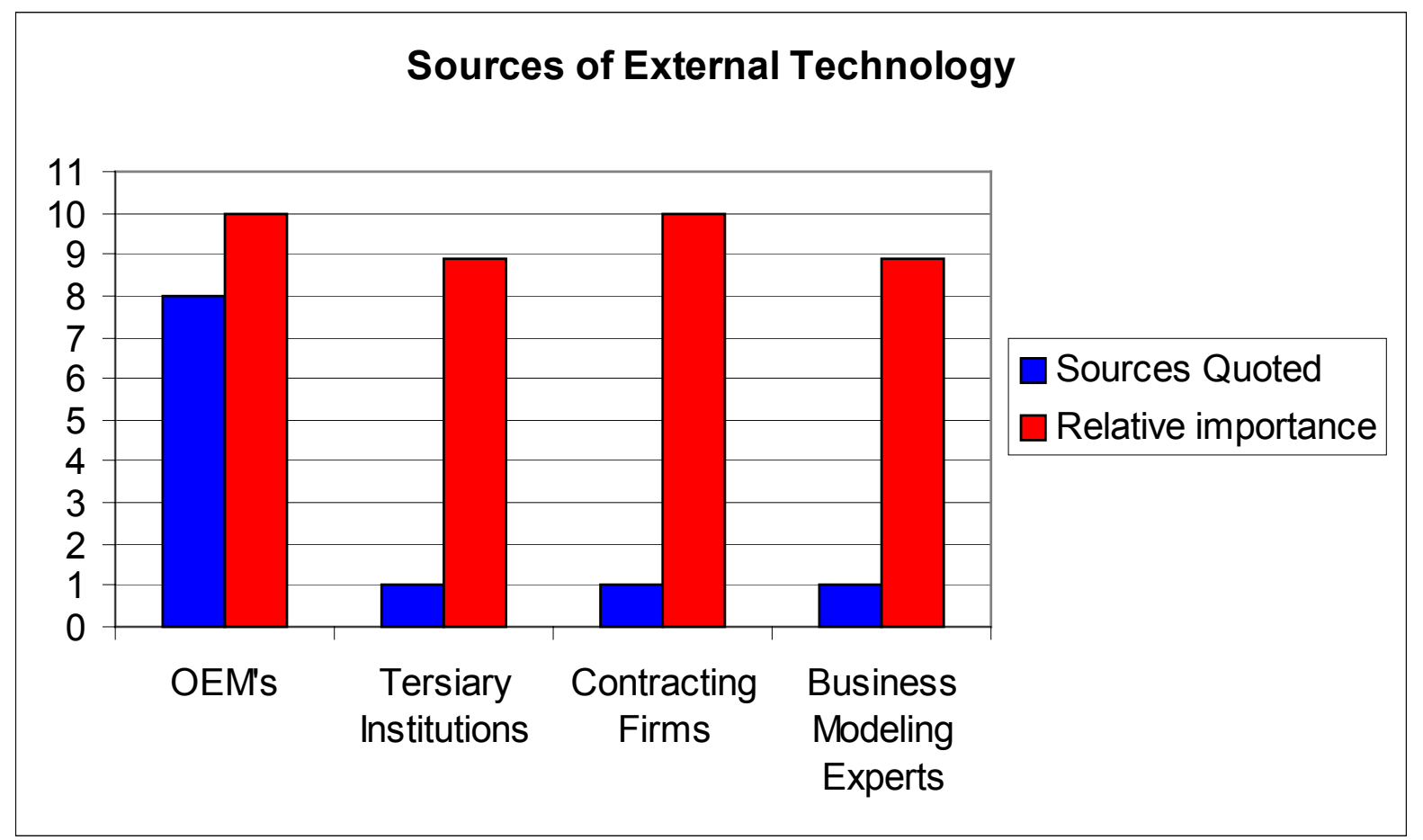

Figure 1: External Technology Sources

In response to the question whether transferred technology enhanced the level of maintenance operations eight respondents responded 'yes' while two responded 'no'.

Six respondents felt that there is a gap between the technology utilised by their organisation and the technology that is available to the industry. Three respondents felt that there was no gap, while one respondent replied 'don't know'. The severity of the gap was indicated to be 5.9 out of ten with one indicating a severe gap and ten indicating an insignificant gap. 
On the question whether there is a formal technology transfer programme present in the respective companies, seven respondents were not sure, while two respondents replied 'yes' and one responded 'no'.

Figure 2 indicates the mechanisms used in the transfer of technology.

Figure 3 indicates the possible barriers to transfer as indicated by the respondents in the questionnaire.

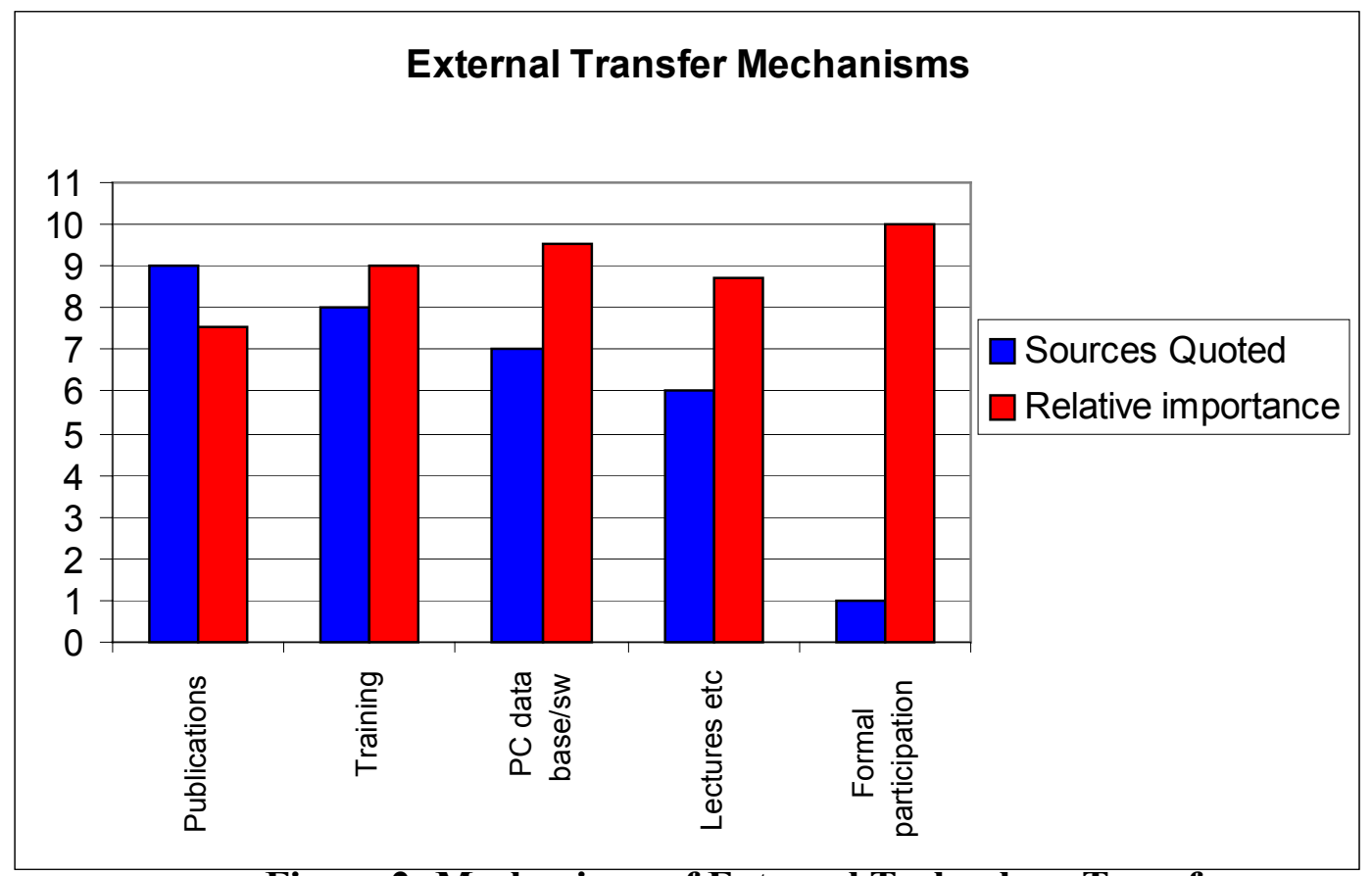

Figure 2: Mechanisms of External Technology Transfer

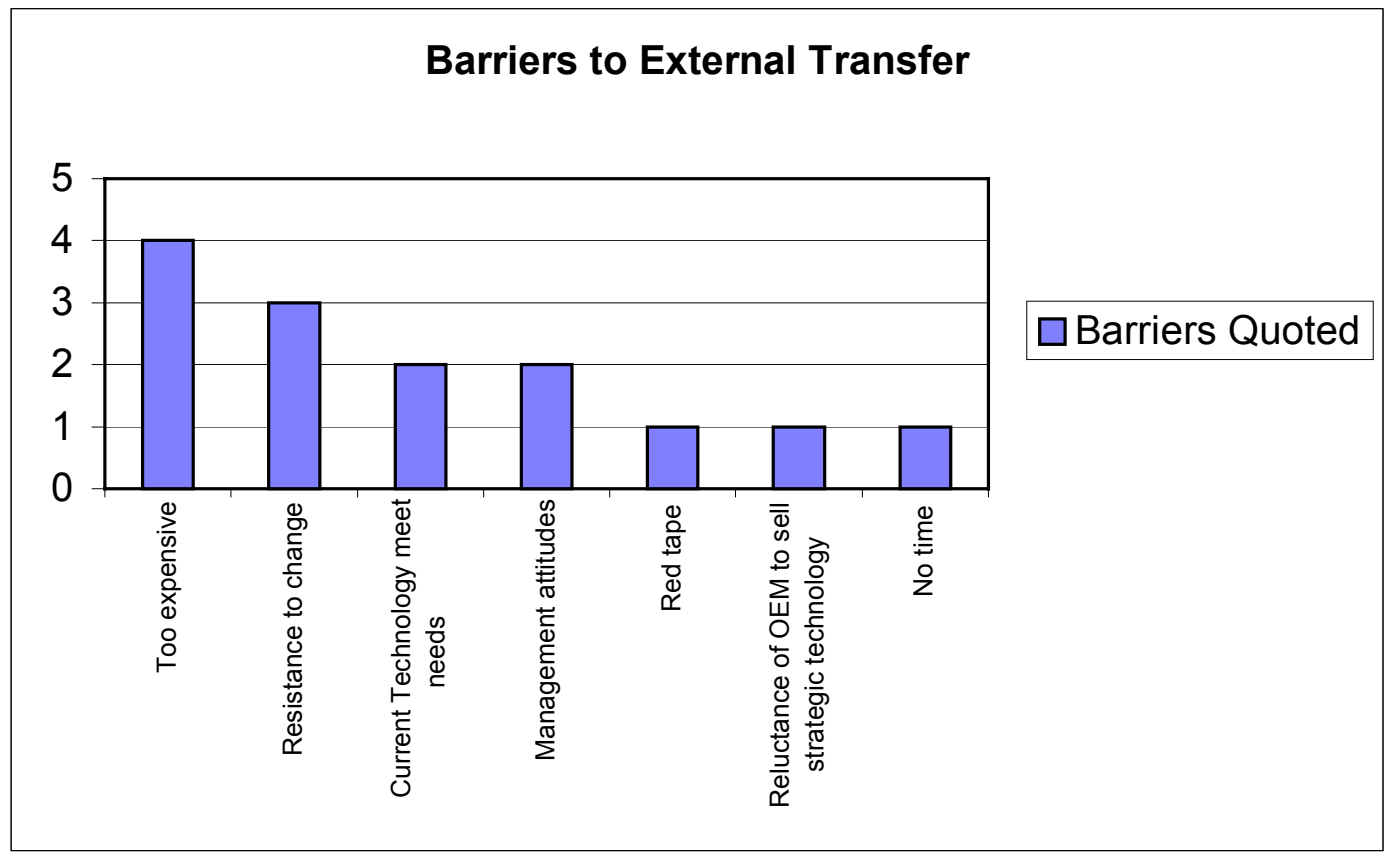

Figure 3: Barriers to External Technology Transfer 
Nine respondents felt that their companies invested in appropriate technology while one believed his/her company does not invest in the most appropriate technology. From the research done it is clear that the main external source of technology is Original Equipment Manufacturers (OEMs). The needs of the aviation industry are therefore satisfied mainly by equipment supplied by OEMs. A certain level of skill and knowledge is needed in order to use the equipment properly and therefore all three aspects of technology are present. The research also indicates that there is a gap between the technology that is used in the industry, and the technology that is available. The severity of the gap translates into being restrictive. There are therefore needs that cannot be satisfied by the current technology.

The mechanisms used to transfer the technology can be seen in Figure 2. It is interesting to see that publications, mainly in the form of manuals, are the most widely used while the relative importance is rated as the lowest of the mechanisms used. On the other end of the scale, formal participation is utilised the least, and its relative importance is rated the highest of the mechanisms used. This may be because the concept of formal participation during an acquisition programme is a newer concept to the local aviation industry, and although it is seen to be important, it is not widely used yet.

The biggest barrier to external technology transfer is the cost of the technology. This point was also raised in the interviews. It seems that the individual companies just do not have enough money to buy the most appropriate technology. This may be the main reason for the gap between available and current technologies. A solution to this problem may lie in the nature of the relationship between the supplier of the technology and the user. They might consider entering collaborative agreements where the traditional supplier - user relation makes way for a more mutually beneficial agreement, in which both parties gain in terms of technology. In short they can pay for technology with technology. This might be a very important point to consider. Another important aspect is that there does not seem to be dedicated personnel looking after technology transfer aspects in the respective companies. Most of the respondents were unsure if there were dedicated transfer policies or programmes in their companies. If a section identifies a need they are responsible for transferring the appropriate technology. This can work, but is not the most effective strategy. Personnel often do not have the appropriate skills to manage these types of projects. A dedicated team with the appropriate skills should be exposed to various transfer projects, thereby gaining valuable experience in this field.

Most respondents felt that their companies transfer appropriate technology. During the interviews however, people complained about the fact that not all the parties concerned are consulted when new technology is considered for the companies. Poor communication was sighted as a major problem in this regard.

\subsubsection{Internal Technology Transfer}

Eight respondents indicated that their companies have training programs with the aim of transferring technology internally, while two respondents indicated that there are no such programmes. The sources used for technology and the perceived effectiveness (measured on a scale out of ten) is summarised by Figure 4. 


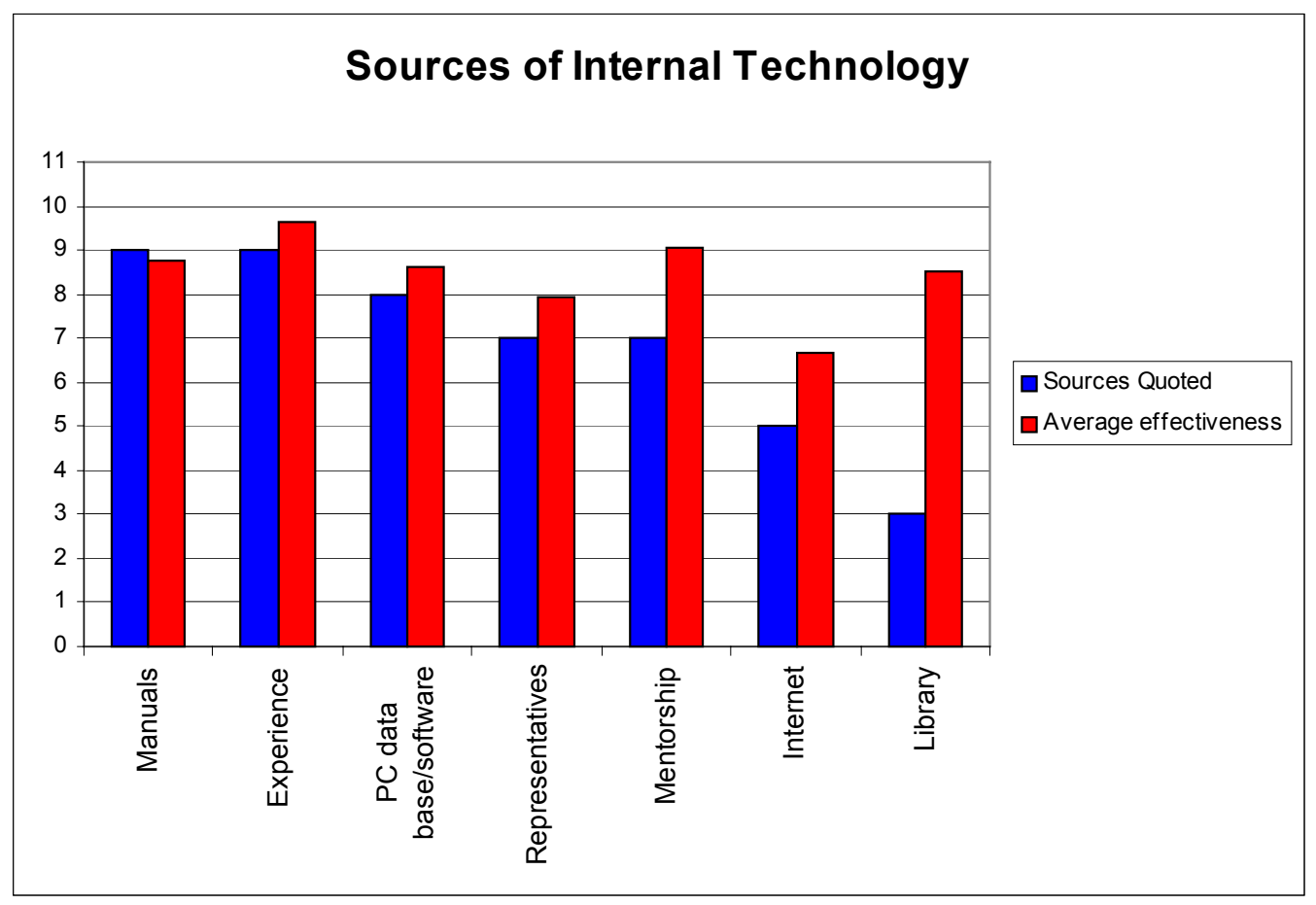

Figure 4: Sources of Internal Technology Utilised

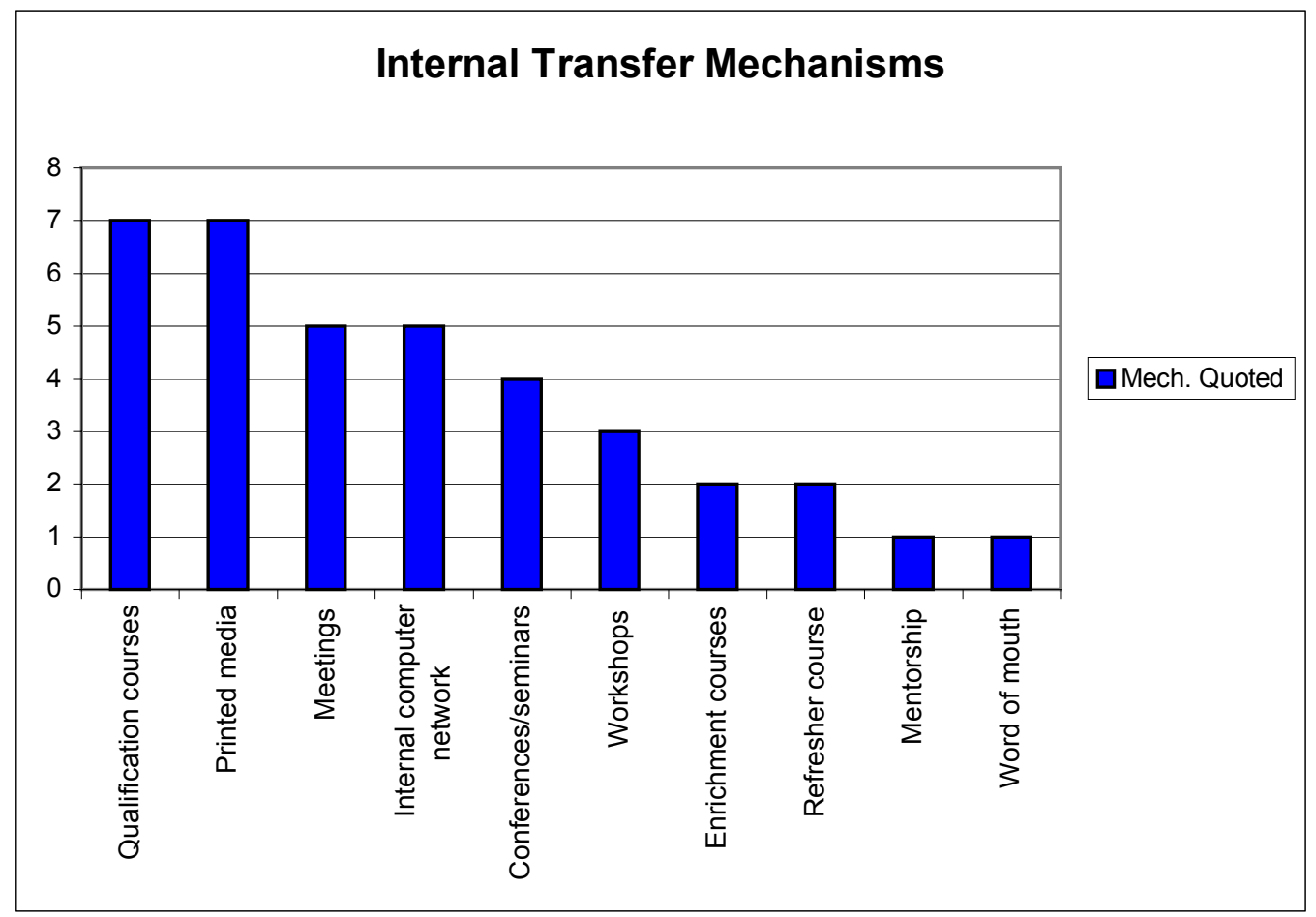

Figure 5: Mechanisms used in Internal Technology Transfer 


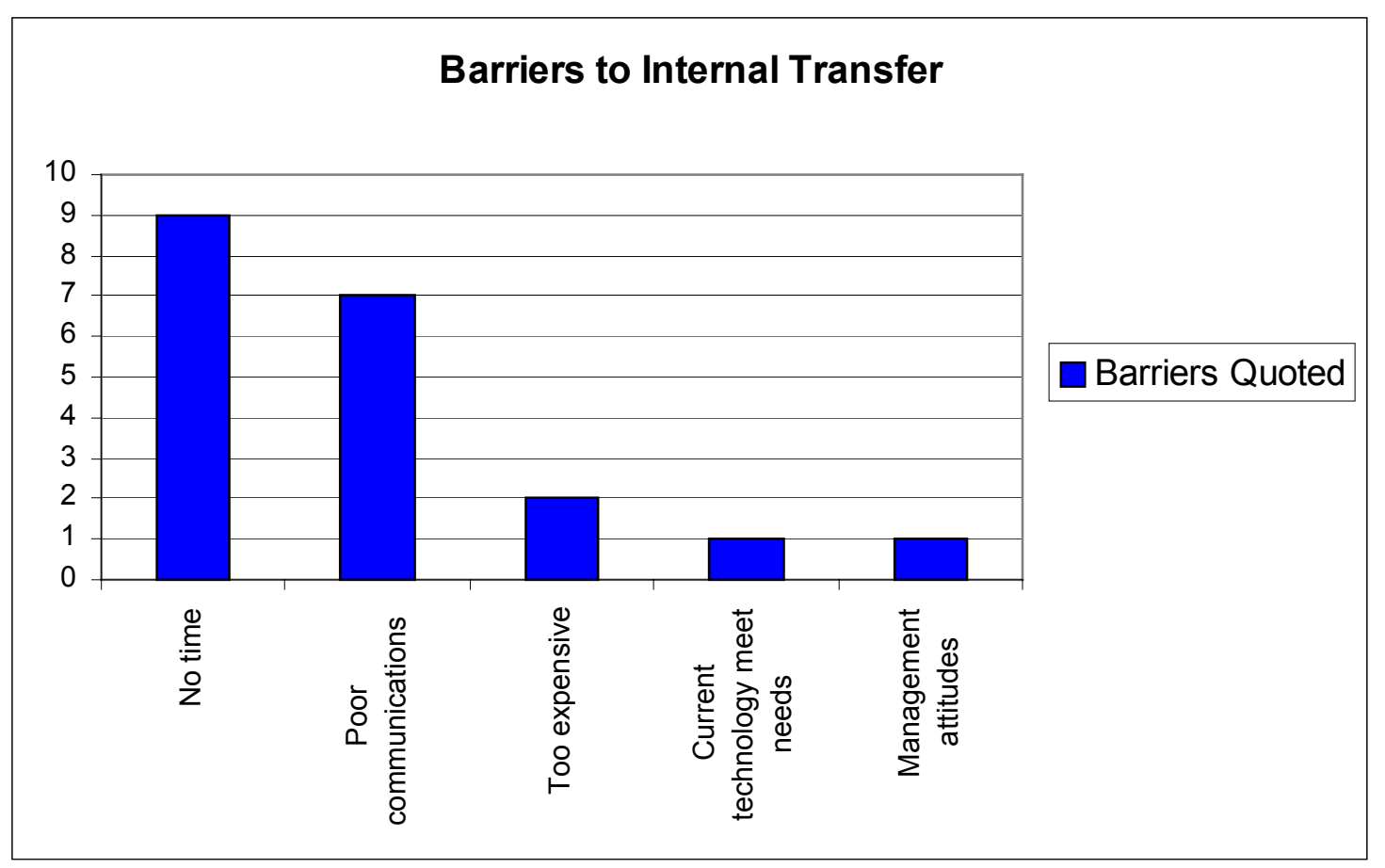

Figure 6: Barriers to Internal Technology Transfer

Figure 5 indicates the mechanisms used to transfer technology internally. Seven respondents indicated that direct assistance is the most effective of the mechanisms used. The barriers to internal transfer is illustrated in Figure 6

Only two respondents indicated that they believed that the technologies available in their companies are fully exploited and five indicated that the technologies utilised in the companies are appropriate.

Figure 4 shows the sources of technology utilised in the companies. Manuals together with experience were identified as the most often used sources. Experience is also identified as the most effective source. The companies should therefore look at this source of knowledge and skills and make sure that the attributes these personnel posses are fully exploited and that they are rewarded for their effort. Structures should also be in place to ensure that the skills and knowledge is transferred from the experienced personnel to the rest of the company.

The main mechanisms used to transfer technology or part of it internally is by way of qualification courses, direct assistance and printed media with direct assistance being used the most. This may be because experience is one of the main sources of technology. Experienced people assist less experienced people and therefore it is one of the main mechanisms of transfer.

The main barriers to internal transfer of technology were lack of time and poor communications. Poor communication was also mentioned in the interviews as being one of the main obstacles. Also mentioned was the fact that personnel have work that must be completed on time and that they do not have time for anything else except their work. Again, 
having certain people look after the transfer process may be the answer. This is however a bit difficult, because internal transfer has mostly to do with the broadening of the individuals' knowledge and skills base. In order to realise this individuals will have to attend courses and training sessions, etc. In the interviews it was indicated that there simply was not time to do this.

\subsection{Discussion of Hypotheses}

The research results supported Hypothesis 1. All the respondents acknowledged the fact that they do transfer technology due to the fact that most technology is developed outside their organisations.

The research results did not support Hypothesis 2. The transfer processes as used in the respective companies were perceived to be very effective. It seems that the years of isolation did not have the negative impact that was thought it should have had. The effectiveness of the transfer projects may also be the result of the culture of 'we can make anything work', an attitude that is the result of the fact that the industry had to be self-sufficient.

The research results supported Hypothesis 3. The research indicates that there is a gap between the technologies used in the companies and the technologies available to the companies. The severity of the gap was indicated to be restricting. The gap may be the result of the barriers to the transfer of technology especially factors like cost.

The research results supported Hypothesis 4. There are no dedicated people concerned with managing technology and the transfer thereof. During the interviews there was great uncertainty as to whether there are formal strategies or programmes for the transfer of technology. The transfer projects are done in an informal way with the individual sections responsible for the transfer of the technology.

The research results supported Hypothesis 5. The barriers to the transfer process are indicated in Figure 3 and Figure 6. As can be seen in these graphs the barriers to transfer are not the same between the external and the internal transfer environments. This is due to the fact that these two environments are subjected to different difficulties, which eventually forms barriers to the smooth transfer of technology.

The research results also supported Hypothesis 6 . The majority $(80 \%)$ of the respondents indicated that the technologies used in their organisations are not fully exploited. This may be due to the fact that the knowledge component in the transfer process is not sufficiently transferred. In short, workers may not be sufficiently trained in order to exploit the transferred technology fully.

\section{RESEARCH FINDINGS}

During the research, most respondents indicated that their respective companies utilise the opportunity to transfer technology, if the need arises. Most respondents however also indicated that their respective companies do not have formal technology transfer strategies or programmes in place. This means that there are not dedicated people looking after transfer 
projects. At this moment 'non specialists' therefore oversee transfer projects. The section, to which the technology is transferred, is therefore also responsible for the management of the project. The positive side of this situation is that the people involved in the transfer process are knowledgeable on the technical aspects of the project, but are they competent in the management of the project?

By having dedicated people specialising in the management of the project, the efficiency of the total project will be improved. Due to the fact that most respondents indicated that their respective companies do not have formal technology transfer strategies in place, a model is proposed to assist in establishing a formal strategy. The model also aims to introduce the basic aspects involved in a transfer project. Not only can the model be used in the early planning stages of a project; it can also be used during the project as a guide to measure the progress and output of the project.

\section{THE FUTURE}

What will the future hold for maintenance in the aviation industry? If this question can be answered companies can identify technologies that can help them in the future to streamline their operations. Unfortunately no one can answer this question, but certain trends in the industry can be identified. If these trends are expected to continue one can identify technologies that may be used to further support these trends. These technologies may provide a competitive edge. The aim of this chapter is therefore to identify trends that are believed to continue in the industry and if the trends are identified, companies can identify technologies that may support these trends in the future. Companies can then decide whether or not to invest in such technologies.

A major trend is for established maintenance functions of larger airlines to move outside the airline and function as a separate independent business. This trend is expected to continue in future, due to the fact that airlines want to focus on their core business function of providing a service of transporting passengers and cargo between destinations. Airlines feel that major maintenance is not part of their core business and therefore they are moving this business function outside the airline. These newly formed maintenance companies compete for maintenance work and even compete for work from their old allies. These companies will not only compete on the quality of work, but will also compete on turn around time. This may become the most important aspect in the competition between independent maintenance houses.

Time is a very important aspect to the airlines, because an aircraft standing on the ground is not earning revenue and it is therefore very important to minimise the time aircraft spend on the ground. It is so important that even acceleration clauses in the maintenance contracts may be an important economical consideration. This boils down to a situation where an airline is prepared to pay more for the maintenance of their aircraft if the maintenance can be done in a shorter period of time.

In future we will see that independent maintenance houses will do most of the maintenance work in the aviation industry. We will also see the trend that these houses will specialise in a certain aspect of maintenance in the industry, for example the maintenance of engines. The 
industry will also see a growing trend in outsourcing, because in certain specialised maintenance tasks the market is not big enough to warrant the training and employment of resources for such specialised tasks. Therefore larger maintenance companies will outsource maintenance work of this kind. This is especially true for the South African aviation industry.

Another trend that is thought to continue is the repair of components. Airlines have achieved big saving by repairing components and not replacing them with new components. There are very significant developments in the technology of repairing components. The South African industry should seriously consider this market, for it is geared to repair most components. This is because of the fact that they were forced to be self-sufficient in the past and they did not have access to new parts and were therefore forced to repair parts.

Maintenance, especially that of components, will therefore move outside the airlines and will be performed by separate companies. We will see a fragmented industry with many small companies, each specialising in an aspect of maintenance. These companies will each stick to their core business and will be very competitive. These companies will compete in terms of time and cost. Their performance will be scrutinised by governing bodies like the FAA, and the feeling is that the quality of work will be of a uniformly high standard.

Line maintenance is expected to stay within the airlines. Line maintenance includes the monitoring and co-ordinating of all technical aspects concerning the operations of a fleet of aircraft. It also includes functions like visual inspections, replacement of consumables like oil, the monitoring of the condition of components and the replacement of faulty components. It does not include the repair of components. Airlines will therefore assume the responsibility of co-ordinating the maintenance function and perform routine tasks, without getting involved in the physical repair of the components.

This function is expected to be performed from a central location, which will be called the brain of the operation, or, as one airline described it 'the bridge of command'. Employing some innovative technology, it will be possible for the brain to perform its duties over the globe, wherever aircraft belonging to the airline might be. The brain will have access to all relevant information necessary, to perform its duties, from spare part listings to relevant information on each individual aircraft. In the brain, highly qualified, competent people will monitor the progress of their fleet all over the world. All technical problems will be communicated to the brain, where decision-makers will recommend corrective action after considering all relevant information. The information the brain receives will either be directly from the onboard computer of the aircraft, or it will be from a technician on the ground, who is servicing the aircraft.

Not only will the technicians of the future be equipped with the traditional toolbox, but they will also be equipped with technology that will directly connect them visually with the brain. A small camera will allow co-ordinators in the brain to exactly see what the technician is doing. Tasks like visual inspections will 'physically' be performed by the technician, but 'mentally' by the co-ordinator. The skills will therefore reside with the technician and the knowledge with the co-ordinator. In the case where a component must be replaced, the coordinator will guide the technician through the process on how to perform the task. The procedure will be monitored by the co-ordinator, because he is in visual contact and the co- 
ordinator can, at any time, consult the procedure manual, because he has instant access to it. The technician will therefore act as remote robot, 'controlled' by the co-ordinator. The coordinator will act as the brain and the technician as the hand. The brain will possess all the knowledge, know-how and decision-making capabilities, while the technician will possess the skills of performing the required actions.

The line maintenance system is shown in Figure 7, which approximates the physiological system of the human body. The whole system is considered to be a technology and this might be the way line-maintenance technologies are headed in the future.

\section{Technology}

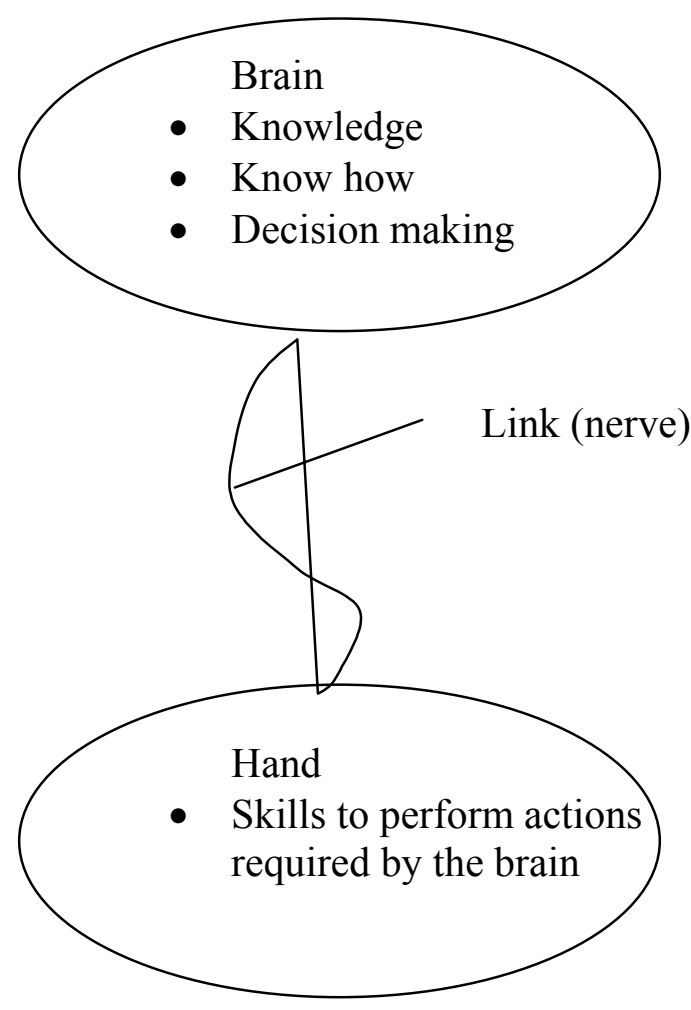

Figure 7: Line maintenance system

\section{CONCLUSION}

The fact that technology plays an increasingly important role in the modern organisation cannot be denied. Organisations around the globe invest in the research and development of new technology, because of the great potential new innovative technologies may hold. These organisations not only invest in new technology but also spend a great deal on the proper management of current technology.

This may be the greatest stumbling block for South African companies especially those in the aviation industry. The research indicated that the greatest barrier for external transfer of technology is the lack of sufficient funds. A strategy that may be considered is entering 
mutually beneficial partnerships where new state of the art technology is exchanged for locally existing technology.

The research also indicated that the respective companies do not have formal technology transfer strategies in place. Being a special kind of project, the transfer of technology should be handled by people with the relevant skill and expertise. It has become a specialised function and many organisations are appointing Technology Managers, with the task of managing all technological issues. This is a strategy that may be considered by the South African industry. There may be several advantages in employing dedicated people to look after the technological position of a company. These people will have extensive knowledge on the technology used by their company, the technology that is available and the technologies used by their main competitors. They will also know the technological potential of the current technology, and will therefore be able to advise on the maximal exploitation of the current technology. This is very important in any competitive market, where organisations strive to do the most with the technology available to them.

\section{REFERENCE}

[1] Le Grange, L.I. and Buys, A.J., 2002. "A Review of Technology Transfer Mechanisms", South African Journal of Industrial Engineering, Vol. 13 No 1, pages 81 -99 . 